\title{
Impacted large ureteral stone: What is the best approach?
}

\author{
Fábio C. M. Torricelli ${ }^{1}$ \\ ${ }^{1}$ Divisão de Urologia do Hospital das Clínicas da Faculdade de Medicina da Universidade de São Paulo. \\ São Paulo, SP, Brasil
}

\section{COMMENT}

Treatment of impacted large ureteral stone is a challenging procedure for endourologists. Several options are available including retrograde ureteroscopy (URS), anterograde percutaneous access, shockwave lithotripsy (SWL) and transperitoneal or retroperitoneal laparoscopic ureterolithotomy (1-3). EAU and AUA guidelines recommend retrograde flexible ureteroscopy or percutaneous approach as first options for large ureteral stones management based on their high stone-free rate and minimal invasiveness $(4,5)$. Gökce et al. performed an interesting study comparing anterograde and retrograde access for large ureteral stone in elderly population (6). They have reported a higher stone-free rate with mini-percutaneous access (16 Fr) and similar complication rate when compared to URS. Main limitations were the lack of randomization process and no sample size calculation in the methodology. Another point the deserve attention was the low frequency of flexible device in the percutaneous access (7\%, 5 of the 68 cases).

Previous studies have demonstrated the elderly population when submitted to percutaneous nephrolitotomy (PCNL) can experience more complications and longer hospital stay $(7,8)$. In a systematic review and meta-analysys, De et al. have reported that PCNL is associated with higher stone-free rate at the expense of higher complication rate, blood loss, and admission time when compared to retrograde intrarenal surgery (9). Mini-percutaneous access seems to be an option to minimize surgical complications, especially in high-risk patients as elderly. Gao et al. have reported the outcomes of a systematic review and meta-analysis including 5 randomized clinical trials comparing mini-PCNL and URS for the treatment of large ureteral stones. Mini-percutaneous access provided higher stone-free rate and similar complication rate than URS. URS had a shorter hospital stay (10).

In a recent published systematic review and meta-analysis including 12 randomized clinical trials and 1416 patients comparing laparoscopic ureterolithotomy (LU), PCNL and URS, authors have found that PCNL and LU achieved a higher stone-free rate and a lower ureteral injury rate than URS (1). In another systematic review and meta-analysis including 25 studies and 2888 patients comparing SWL, PCNL, URS and LU for large ureteral stone management, authors have reported LU as the method with higher stone-free rate and complication rate only superior to SWL (3). These meta-analyses show that endourolgists who have experience with laparoscopic surgery have one more interesting option when deciding the best approach for an impacted large ureteral stone.

\section{CONFLICT OF INTEREST}

None declared. 


\section{EDITORIAL COMMENT}

\section{REFERENCES}

1. Lai S, Jiao B, Diao T, Seery S, Hu M, Wang M, et al. Optimal management of large proximal ureteral stones (>10 mm): A systematic review and meta-analysis of 12 randomized controlled trials. Int J Surg. 2020;80:205-17.

2. Torricelli FC, Monga M, Marchini GS, Srougi M, Nahas WC, Mazzucchi E. Semi-rigid ureteroscopic lithotripsy versus laparoscopic ureterolithotomy for large upper ureteral stones: a meta - analysis of randomized controlled trials. Int Braz J Urol. 2016;42:645-54.

3. Wang $Y$, Chang $X$, Li J, Han Z. Efficacy and safety of various surgical treatments for proximal ureteral stone $\geq 10 \mathrm{~mm}$ : $A$ systematic review and network meta-analysis. Int Braz J Urol. 2020;46:902-26.

4. Türk C, Petcík A, Sarica K, Seitz C, Skolarikos A, Straub $\mathrm{M}$, et al. EAU Guidelines on Interventional Treatment for Urolithiasis. Eur Urol. 2016;69:475-82.

5. Assimos D, Krambeck A, Miller NL, Monga M, Murad MH, Nelson CP, et al. Surgical Management of Stones: American Urological Association/Endourological Society Guideline, PART II. J Urol. 2016;196:1161-9.
6. Gökce MI, Akpinar Ç, Obaid K, Süer E, Gülpinar Ö, Bedük Y. Comparison of retrograde ureterorenoscopy (URS) and percutaneous anterograde ureteroscopy for removal of impacted upper ureteral stones $>10 \mathrm{~mm}$ in the elderly population. Int Braz J Urol. 2021;47:64-70.

7. Nakamon T, Kitirattrakarn P, Lojanapiwat B. Outcomes of percutaneous nephrolithotomy: comparison of elderly and younger patients. Int Braz J Urol. 2013;39:692-700; discussion 701.

8. Torricelli FCM, Ogawa GKM, Vicentini FC, Marchini GS, Danilovic A, Srougi M, et al. Supine percutaneous nephrolitotripsy in septuagenarian and octogenarian patients: outcomes of a case-control study. Can J Urol. 2018;25:9245-9.

9. De S, Autorino R, Kim FJ, Zargar H, Laydner H, Balsamo $\mathrm{R}$, et al. Percutaneous nephrolithotomy versus retrograde intrarenal surgery: a systematic review and meta-analysis Eur Urol. 2015;67:125-37. Erratum in: Eur Urol. 2016;69:e85

10. Gao ZM, Gao S, Qu HC, Li K, Li N, Liu CL, et al. Minimally invasive percutaneous nephrolithotomy improves stone-free rates for impacted proximal ureteral stones: A systematic review and meta-analysis. PLoS One. 2017;12:e0171230.

ARTICLE INFO

Torricelli FC https://orcid.org/0000-0002-5845-0894

Int Braz J Urol. 2021; 47: 71-2

Fabio C. M. Torricelli, MD

Divisão de Urologia do Hospital das Clínicas da Faculdade de Medicina da Universidade de São Paulo

Rua Barata Ribeiro, 380, conj. 74

São Paulo, SP, 01308-000, Brasil

Telephone: + 5511 2768-4552

E-mail: fctorricelli@yahoo.com.br

Submitted for publication: August 01, 2020

Accepted:

August 10, 2020 